International Journal of Mechanical Engineering and Technology (IJMET)

Volume 11, Issue 10, October 2020, pp. 1-12, Article ID: IJMET_11_10_001

Available online at https://iaeme.com/Home/issue/IJMET?Volume $=11 \&$ Issue $=10$

ISSN Print: 0976-6340 and ISSN Online: 0976-6359

DOI: https://doi.org/10.34218/IJMET.11.10.2020.001

(C) IAEME Publication

Scope Database Indexed

\title{
INVESTIGATION OF COATING THICKNESS, HARDNESS AND WEAR RESISTANCE OF ALUMINUM 6061 BY ANODIZING TREATMENT
}

\author{
Agus Suprapto, Pungky Eka Setyawan*, Dewi Izzatus Tsamroh \\ Department of Mechanical Engineering, \\ University of Merdeka Malang, Malang, Indonesia. \\ *Corresponding Author
}

\begin{abstract}
Aluminum 6061 has the advantages such as good formability, corrosion resistance and lightweight, but it also has weaknesses, such as its hardness andwear resistance are relatively low, thus anodizing process is conducted to increase its hardness and wear resistance. The anodizing process can also produce a more attractive appearance and texture of metal. It alsocan increase the resistance of surface friction. The anodizing technique isa metal plating processbased on the formation of an aluminum oxide coating through controlled oxidation. The quality of the anodizing product is determined by the thicknesses of the coating formed. This study aimed to determine and analyze the mechanical properties and thicknesses of the coating on the surface of aluminum 6061 due to anodizing process. The method used in this research was a laboratory experimental method, with variations of the anodizing solution, voltage, and immersion time. The solutions used in this study were 100\% 1M sulfuric acid, phosphorus acid, and nitric acid. The voltages used in this study were $15 \mathrm{~V}$ and $30 \mathrm{~V}$, while the immersion time variation of the anodizing process was carried out at 10 minutes and 30 minutes. The mechanical properties of anodizing aluminum 6061 were tested using hardness and wear resistance tests. The data that had been obtained were analyzed using the descriptive analysis method. The results showed that the highest hardness rate was obtained in the treatment with the use of $100 \% \mathrm{H}_{2} \mathrm{SO}_{4}$ anodizing solution, with a voltage of $15 \mathrm{~V}$, which was immersed for 30 minutes. The highest hardness reaching $106.47 \mathrm{HV}$ was found in specimen number 2, with a wear resistance of $17153.09 \mathrm{~m} / \mathrm{g}$, and a coating thickness of $57.025 \mu \mathrm{m}$.
\end{abstract}

Keywords: Anodizing solution, coating thickness, hardness, wear resistance, aluminum 6061.

Cite this Article: Agus Suprapto, Pungky Eka Setyawan, Dewi Izzatus Tsamroh, Investigation of Coating Thickness, Hardness and Wear Resistance of Aluminum 6061 by Anodizing Treatment. International Journal of Mechanical Engineering and Technology. 11(10), 2020, pp. 1-12.

https://iaeme.com/Home/issue/IJMET?Volume $=11 \&$ Issue $=10$ 


\section{INTRODUCTION}

Aluminum is one type of non-ferrous metal that is most widely used in the world, especially in the automotive, aircraft industry, manufacturing industry, and household appliances, this is because aluminum has several advantages such as being lightweight, resistant to corrosion, cheap, and easy to be formed [1]. However, when compared to other commercial metals, aluminum has a relatively lower hardness and wear resistance [2, 3]. Previous research about the use of anodizing treatment showed changes in hardness with variations in electrolyte solutions [4]. The value of anodizing hardness is inversely proportional to the value of the wear rate of aluminum. Meanwhile, the pore thickness on anodizing,was affected by the potential difference [5], the potential difference of $25 \mathrm{~V}$ resulting in an average pore thickness of $18.33 \mu \mathrm{m}$. Another previous research showed that the highest wear resistance were $47.33 \%$ in the degreasing composition in anodizing process: $85 \%$ Phosphorous; $15 \% \mathrm{H}_{2} \mathrm{SO}_{4} ; 0 \% \mathrm{HNO}_{3}$ with an anodizing time for 30 minutes. Meanwhile, the lowest wear resistance was 22, 54\% that found in the degreasing composition: $75 \%$ Phosphorous; $20 \% \mathrm{H}_{2} \mathrm{SO}_{4}$; and $5 \% \mathrm{HNO}_{3}$ with an anodizing time for 10 minutes [6]. The wear rate of aluminum alloy AA 2024-T3 can be reduced from $1.66 \times 10^{-6} \mathrm{~g} / \mathrm{cm}$ to $9.21 \times 10^{-8} \mathrm{~g} / \mathrm{cm}$ by the anodizing process with a current density of $3.00 \mathrm{~A} / \mathrm{dm}^{2}$ and immersion time for 60 minutes [4].

Based on the above background, further research is needed to complement the results of previous researches related to the use of anodizing treatment with variations in the type of solution, voltage, and anodizing time, especially in 6061 aluminum material.

\section{METHODOLOGY}

The research method used in this study was a laboratory experimental study. The research was carried out in several steps, which were preparation, anodizing process and ended with testing the research specimen.

Table 1 Specimen numbering and treatment type.

\begin{tabular}{cc} 
Specimen Number & Treatment \\
\hline 1 & $100 \% \mathrm{H}_{2} \mathrm{SO}_{4}, 15 \mathrm{~V}, 10 \mathrm{~min}$ \\
2 & $100 \% \mathrm{H}_{2} \mathrm{SO}_{4}, 15 \mathrm{~V}, 30 \mathrm{~min}$ \\
3 & $100 \% \mathrm{H}_{2} \mathrm{SO}_{4}, 30 \mathrm{~V}, 10 \mathrm{~min}$ \\
4 & $100 \% \mathrm{H}_{3} \mathrm{PO}_{4}, 15 \mathrm{~V}, 10 \mathrm{~min}$ \\
5 & $100 \% \mathrm{H}_{3} \mathrm{PO}_{4}, 15 \mathrm{~V}, 30 \mathrm{~min}$ \\
6 & $100 \% \mathrm{H}_{3} \mathrm{PO}_{4}, 30 \mathrm{~V}, 10 \mathrm{~min}$ \\
7 & $100 \% \mathrm{HNO}_{3}, 15 \mathrm{~V}, 10 \mathrm{~min}$ \\
8 & $100 \% \mathrm{HNO}_{3}, 15 \mathrm{~V}, 30 \mathrm{~min}$ \\
9 & $100 \% \mathrm{HNO}_{3}, 30 \mathrm{~V}, 10 \mathrm{~min}$ \\
\hline
\end{tabular}

The first step was specimen preparation. The material used in this research was aluminum alloy 6061 with dimensions of $10 \mathrm{~mm}$ x $35 \mathrm{~mm}$ x $25 \mathrm{~mm}$. This research was conducted using several independent variables such as variations in the type of anodizing solution, the voltage used in the anodizing process, and the duration of immersion time. Table 1 showed the specimen numbering and the type of treatment performed.

The next step was the anodizing process which included three stages, which were:

1. Pre-treatment, that consisted of:
a. Degreasing
b. Etching
c. Desmutting

2. Anodizing Process

The anodizing process was carried out using a variety of solutions of $100 \% 1 \mathrm{M}$ Sulphuric acid $\left(\mathrm{H}_{2} \mathrm{SO}_{4}\right), 100 \%$ 1M Phosphoric acid $\left(\mathrm{H}_{3} \mathrm{PO}_{4}\right)$, and $100 \% 1 \mathrm{M}$ Nitric acid 
$\left(\mathrm{HNO}_{3}\right)$, and the anode side was connected to an aluminum plate where it had role as the negative pole on the power supply. Furthermore, the voltage adjustment was carried out with a variation of $15 \mathrm{~V}$ and $30 \mathrm{~V}$. The next process was to turn on the power supply, while the anodizing process was carried out with a variation of 10 minutes and 30 minutes.

3. Dying

Dying was the process of drying the specimen after the anodizing process took place.

The next step was the final stage, which was specimen testing which included 4 types of testing as follows:

A. Optical Microscopy

The thicknesses of oxide coating were observed by using optical microscopy.

B. Hardness Test

The surface of the specimens was tested for hardness using a micro Vickers hardness tester.

C. Wear Resistance Test

The wear test on the surface of the anodized specimen was carried out using the Ogoshi wear test equipment, the initial and final weight were weighed with a sliding distance of $171.531 \mathrm{~m}$. The calculation of wear resistance was inversely proportional to the wear rate.

D. Coating Thickness Test

The last test was to collect data on the thickness of the oxide coating that was formed on the 6061 aluminum surface using a Thickness Gun.

\section{RESULT AND DISCUSSION}

This section presents the results of research with various tests on specimens related to the dependent variable, including the hardness of aluminum 6061, wear resistance of aluminum 6061 , and the thickness of the oxide coating formed by the anodizing process. The hardness number was related to the wear resistance, as well as the resulting coating thickness on the surface of the 6061 aluminum specimen.

\subsection{Oxide Coating Thickness}

The following figures are the result of the optical microscopy test.

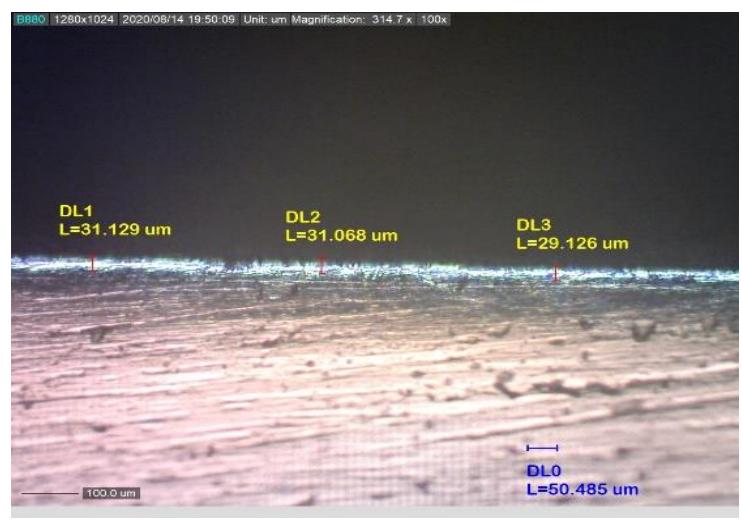

Figure 1. The oxide coating thickness resulted from the anodizing process with a $100 \%$ solution type $1 \mathrm{M}$ Sulfuric acid $\left(\mathrm{H}_{2} \mathrm{SO}_{4}\right)$ with a voltage variation of 15 Volt and immersion time for 10 minutes using a $100 \mathrm{x}$ magnification of optical microscopy 
Investigation of Coating Thickness, Hardness and Wear Resistance of Aluminum 6061 by Anodizing Treatment



Figure 2. The oxide coating thickness resulted from the anodizing process with a $100 \%$ solution type $1 \mathrm{M}$ Sulfuric acid $\left(\mathrm{H}_{2} \mathrm{SO}_{4}\right)$ with a voltage variation of 15 Volt and immersion time 30 minutes using a $100 \mathrm{x}$ magnification of optical microscopy

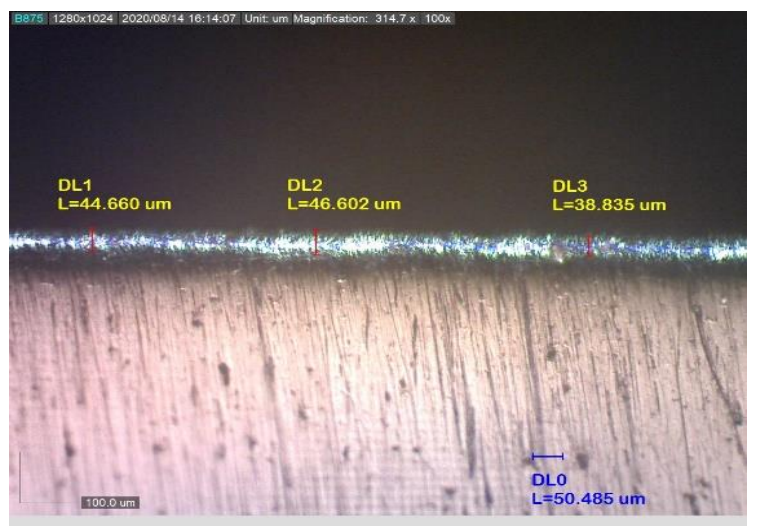

Figure 3. The oxide coating thickness resulted from the anodizing process with a $100 \%$ solution type $1 \mathrm{M}$ Sulfuric acid $\left(\mathrm{H}_{2} \mathrm{SO}_{4}\right)$ with a voltage variation of 30 Volt and immersion time of 10 minutes using an optical microscope $100 \mathrm{x}$

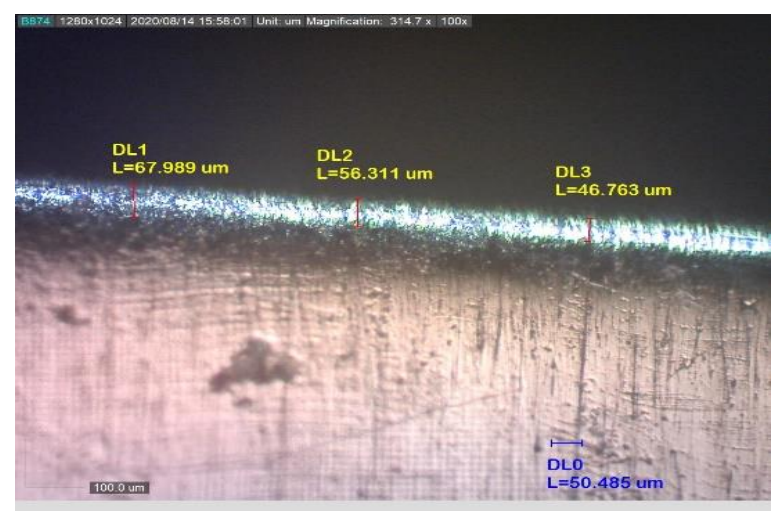

Figure 4. The oxide coating thickness resulted from the anodizing process with a $100 \%$ solution type $1 \mathrm{M}$ Sulfuric acid $\left(\mathrm{H}_{3} \mathrm{PO}_{4}\right)$ with a voltage variation of 15 Volt and immersion time of 10 minutes using an optical microscope 100x 




Figure 5. The oxide coating thickness resulted from the anodizing process with a 100\% solution type $1 \mathrm{M}$ Sulfuric acid $\left(\mathrm{H}_{3} \mathrm{PO}_{4}\right)$ with a voltage variation of 15 Volt and immersion time of 30 minutes using an optical microscope 100x

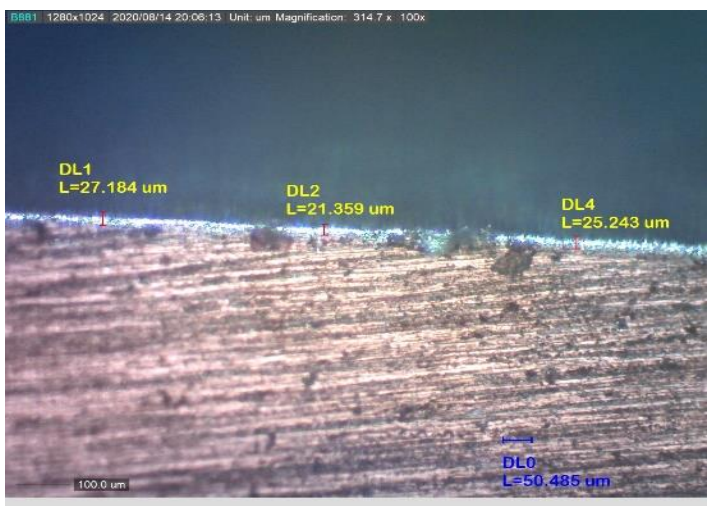

Figure 6. The oxide coating thickness resulted from the anodizing process with a 100\% solution type $1 \mathrm{M}$ Sulfuric acid $\left(\mathrm{H}_{3} \mathrm{PO}_{4}\right)$ with a voltage variation of 30 Volt and immersion time of 10 minutes using an optical microscope $100 \mathrm{x}$

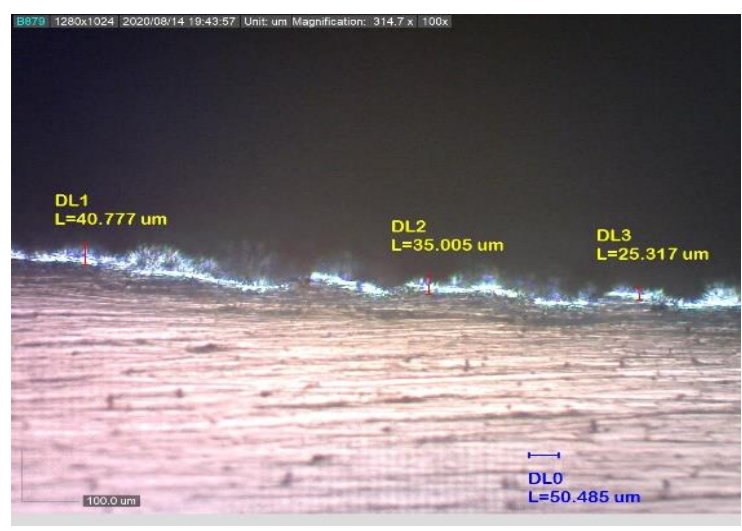

Figure 7. The oxide coating thickness resulted from the anodizing process with a $100 \%$ solution type $1 \mathrm{M}$ Sulfuric acid $\left(\mathrm{HNO}_{3}\right)$ with a voltage variation of 15 Volt and immersion time of 10 minutes using a 100x optical microscope 
Investigation of Coating Thickness, Hardness and Wear Resistance of Aluminum 6061 by Anodizing Treatment

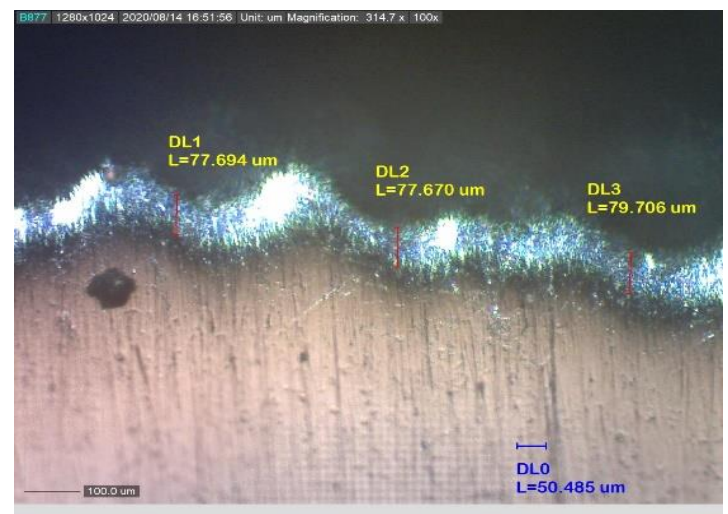

Figure 8. The oxide coating thickness resulted from the anodizing process with a $100 \%$ solution type $1 \mathrm{M}$ Sulfuric acid $\left(\mathrm{HNO}_{3}\right)$ with a voltage variation of 15 Volt and immersion time of 30 minutes using a 100x optical microscope

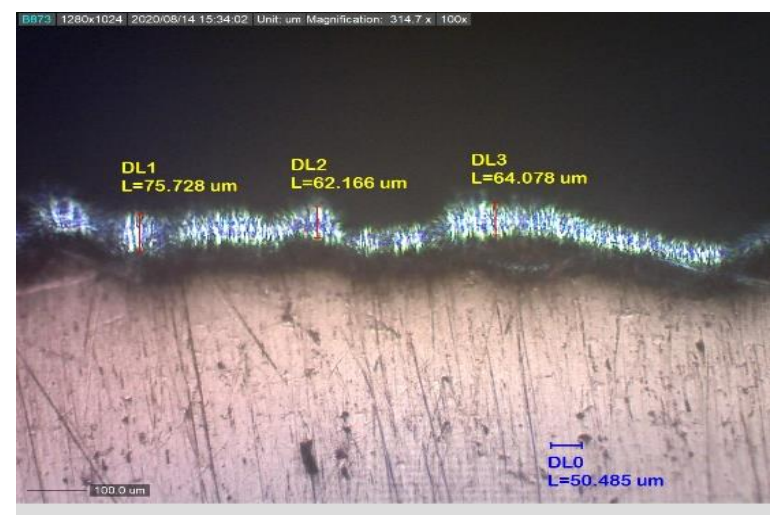

Figure 9.The oxide coating thickness resulted from the anodizing process with a $100 \%$ solution type $1 \mathrm{M}$ Sulfuric acid $\left(\mathrm{HNO}_{3}\right)$ with a voltage variation of 30 Volt and immersion time of 10 minutes using an optical microscope 100x

Based on Table 1, it is known that the thickest oxide coating found in specimens with treatment number 8 , that is by using $100 \% \mathrm{HNO}_{3}$ solution, voltage of $10 \mathrm{~V}$, and immersion time of 30 minutes with a coating thickness of $88.05 \mu \mathrm{m}$. The results of this study are also presented in graphical form in Figure 10.

Table 2.The thickness of the anodizing oxide coating results in variations in time, voltage, and type of solution

\begin{tabular}{llccc}
\hline No & \multicolumn{1}{c}{ Solution Type } & $\begin{array}{c}\text { Voltages } \\
(\mathbf{V})\end{array}$ & $\begin{array}{c}\text { Immersion time } \\
(\text { minute })\end{array}$ & $\begin{array}{c}\text { Oxide Thicknesses } \\
(\boldsymbol{\mu ~ m})\end{array}$ \\
\hline Base Metal & & & \\
\hline 1 & $100 \%$ & 15 & 10 & 24.271 \\
2 & $1 \mathrm{M} \mathrm{Sulfuric}$ acid & 15 & 30 & 53.09 \\
3 & $\left(\mathrm{H}_{2} \mathrm{SO}_{4}\right)$ & 30 & 10 & 57.025 \\
\hline 4 & $100 \%$ & 15 & 10 & 30.44 \\
5 & $1 \mathrm{M} \mathrm{Phosphoric} \mathrm{acid}$ & 30 & 10 & 83.52 \\
6 & $\left(\mathrm{H}_{3} \mathrm{PO}_{4}\right)$ & 30 & 30 & 43.37 \\
\hline 7 & $100 \%$ & 10 & 10 & 33.70 \\
8 & $1 \mathrm{M} \mathrm{Nitric}^{2}$ acid & 10 & 30 & 88.05 \\
9 & $\left(\mathrm{HNO}_{3}\right)$ & 30 & 10 & 67.32 \\
\hline
\end{tabular}

Source: Primary data, processed by researchers, 2020 


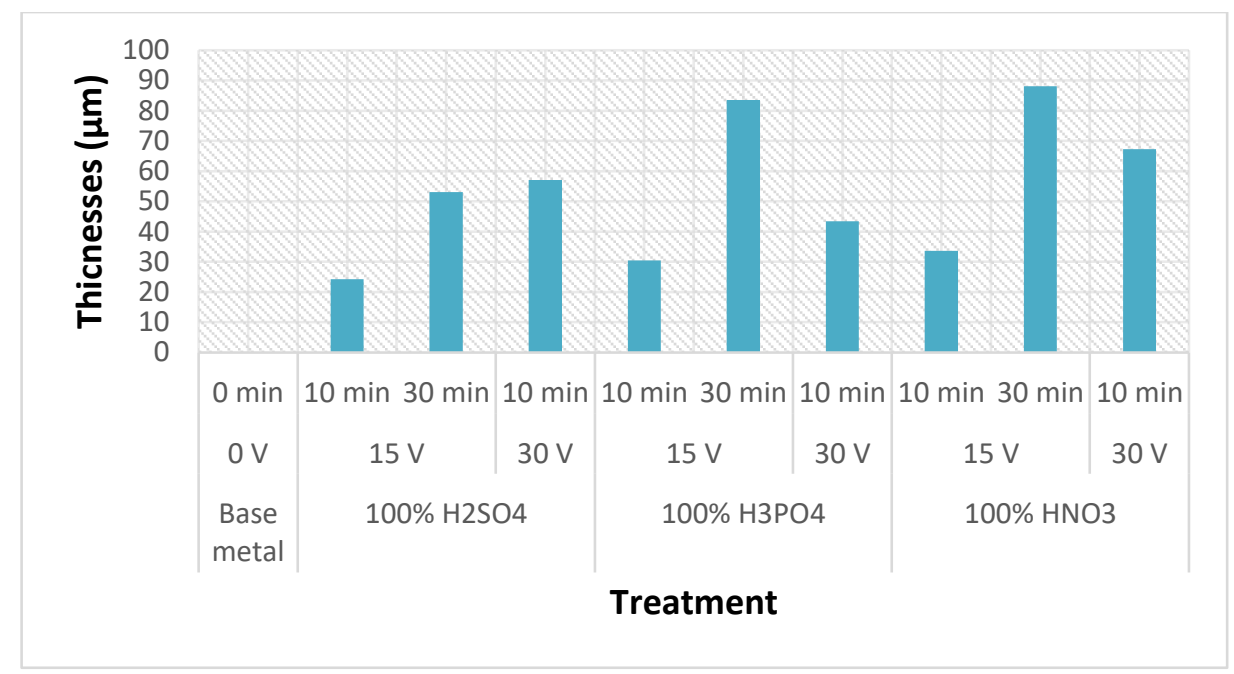

Figure 10. The graph of the thickness of the anodizing oxide coating

Previous research showed that the higher the voltage used, the thicker the resulting oxide coating [7]. The thickness of the oxide coating resulting from the anodizing process is not only affected by the voltage used, but the immersion time in the anodizing process also affects the resulting coating thickness. This is accordance with the result of previous research where the longer time used in the anodizing process will result in a thicker oxide coating [8]. Another research also shows that anodizing time with longer duration results in thicker coating thickness. This research used a variation of anodizing time of 10 minutes, 15 minutes, and 20 minutes, where the thickest coating thickness was found in specimens with an anodizing process for 20 minutes [9].

Based on the results of research that have been carried out and the results of previous studies, the thickness of the oxide coating is significantly affected by the immersion time and the anodizing voltage.

\subsection{Surface Hardness}

Table 2 below shows the hardness value resulting from the anodizing process with variations in the type of solution, voltage, and immersion time. Based on the table above, it's found that the highest hardness number is $106.47 \mathrm{HV}$ resulting from treatment number 2, which is treatment by using $100 \% \mathrm{H}_{2} \mathrm{SO}_{4}$ solution, voltage of $15 \mathrm{~V}$, and immersion time of 30 minutes. The results of this study indicate that using different solutions will affect the hardness of the specimen after receiving anodizing treatment [3].The following figures are the result of the optical microscopy test.

Table 3. The hardness of anodizing results with variations in time, voltage, and type of solution

\begin{tabular}{clccc}
\hline No & \multicolumn{1}{c}{ Solution Type } & Voltages (V) & Immersion time (minutes) & Hardness (HV) \\
\hline Base Metal & \multicolumn{2}{c}{95.80} \\
\hline 1 & $100 \%$ & 15 & 10 & 91.24 \\
2 & $1 \mathrm{M} \mathrm{Sulphuric} \mathrm{acid}$ & 15 & 30 & 101.88 \\
3 & $\left(\mathrm{H}_{2} \mathrm{SO}_{4}\right)$ & 30 & 10 & 94.05 \\
\hline 4 & $100 \%$ & 15 & 10 & 99.20 \\
5 & $1 \mathrm{M} \mathrm{Phosphoric} \mathrm{acid}$ & 30 & 10 & 103 \\
6 & $\left(\mathrm{H}_{3} \mathrm{PO}_{4}\right)$ & 30 & 30 & 95.20 \\
\hline 7 & $100 \%$ & 10 & 10 & 85 \\
8 & $1 \mathrm{M} \mathrm{Nitric} \mathrm{acid}_{9}$ & 10 & 30 & 90.20 \\
\hline
\end{tabular}

Source: Primary data, processed by researchers, 2020 


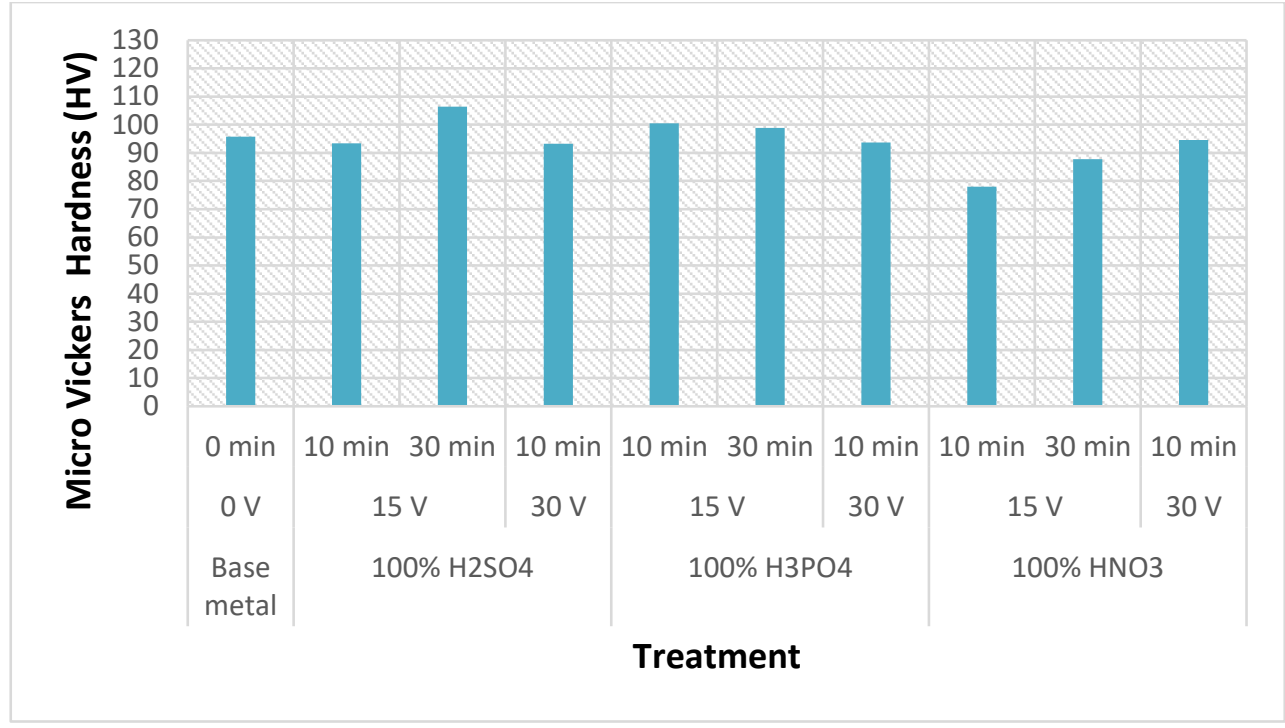

Figure 11. Graph of anodizing hardness on aluminum 6061

The duration of immersing specimens into the anodizing solution has a significant effect on the hardness of aluminum, which is also the case in previous research, which showed that the longer the immersion time of the anodizing process, the specimen's hardness will increase [7]. In this study, the highest hardness was obtained by specimens with an immersion time of 30 minutes, where when compared to the base metal, the hardness of this specimen increased by $13.5 \%$.

The hardness test results are also shown in the graph in Figure 11. Based on Figure 11, the highest hardness is indeed achieved by specimen number 2, however, a significant increase in hardness is achieved in specimens number 7, 8, and 9, which used $100 \% \mathrm{HNO}_{3}$ solution. However, using this type of solution produces a rough surface, which is not a good result for the following processing. The increase in hardness in the anodizing treatment is influenced by the immersion time and the amount of voltage used [10].

\subsection{Wear Resistance}

Table 4 shows the results of the calculation of wear resistance using the Ogoshi method. The highest wear resistance is shown in specimen number 2, while the lowest wear resistance is shown in specimen number 7. This shows that the wear resistance of 6061 aluminum as a result of the anodizing process is influenced by the type of solution, the voltage used, and the anodizing time.

Table 4. Wear resistance of anodizing specimens with variations in time, voltage, and type of solution

\begin{tabular}{clccc}
\hline No & \multicolumn{1}{c}{ Solution Types } & Voltages (V) & $\begin{array}{c}\text { Immersion time } \\
\text { (minutes) }\end{array}$ & $\begin{array}{c}\text { Wear Resistance } \\
(\mathbf{m} / \mathbf{g})\end{array}$ \\
\hline Base Metal & & & 1732,63594 \\
\hline 1 & $100 \%$ & 15 & 10 & 15593,72354 \\
2 & $1 \mathrm{M} \mathrm{Sulphuric} \mathrm{acid}$ & 15 & 30 & 17153,09589 \\
3 & $\left(\mathrm{H}_{2} \mathrm{SO}_{4}\right)$ & 30 & 10 & 17153,09589 \\
\hline 4 & $100 \%$ & 15 & 10 & 3009,31506 \\
5 & $1 \mathrm{M} \mathrm{Phosphoric} \mathrm{acid}$ & 15 & 30 & 10090.0564 \\
6 & $\left(\mathrm{H}_{3} \mathrm{PO}_{4}\right)$ & 30 & 10 & 12252.2113 \\
\hline 7 & $100 \%$ & 15 & 10 & 5045,02820 \\
8 & $1 \mathrm{M} \mathrm{Nitric} \mathrm{acid}_{9}$ & 15 & 30 & 2766,62836 \\
\hline & $\left(\mathrm{HNO}_{3}\right)$ & 30 & 10 & 2450,44227 \\
\hline
\end{tabular}

Source: Primary data, processed by researchers, 2020 
Wear resistance is also related to the hardness of the material, where the higher the hardness of the material, the higher the wear resistance. This is following the results of this study, specimen number 2 has the highest hardness number and has the highest wear resistance, thus, the lowest wear rate is found in specimen number 2.Anodizing treatment on specimen number 2 has increased the wear resistance of aluminum 6061 by 10 times higher than the base metal.

The wear resistance of the anodized specimen is influenced by the voltage and immersion time. The previous research showed that wear resistance increases with the increasing voltage used [11], while another research shows that an increase in specimen hardness was found in the anodizing process for 30 minutes [10].

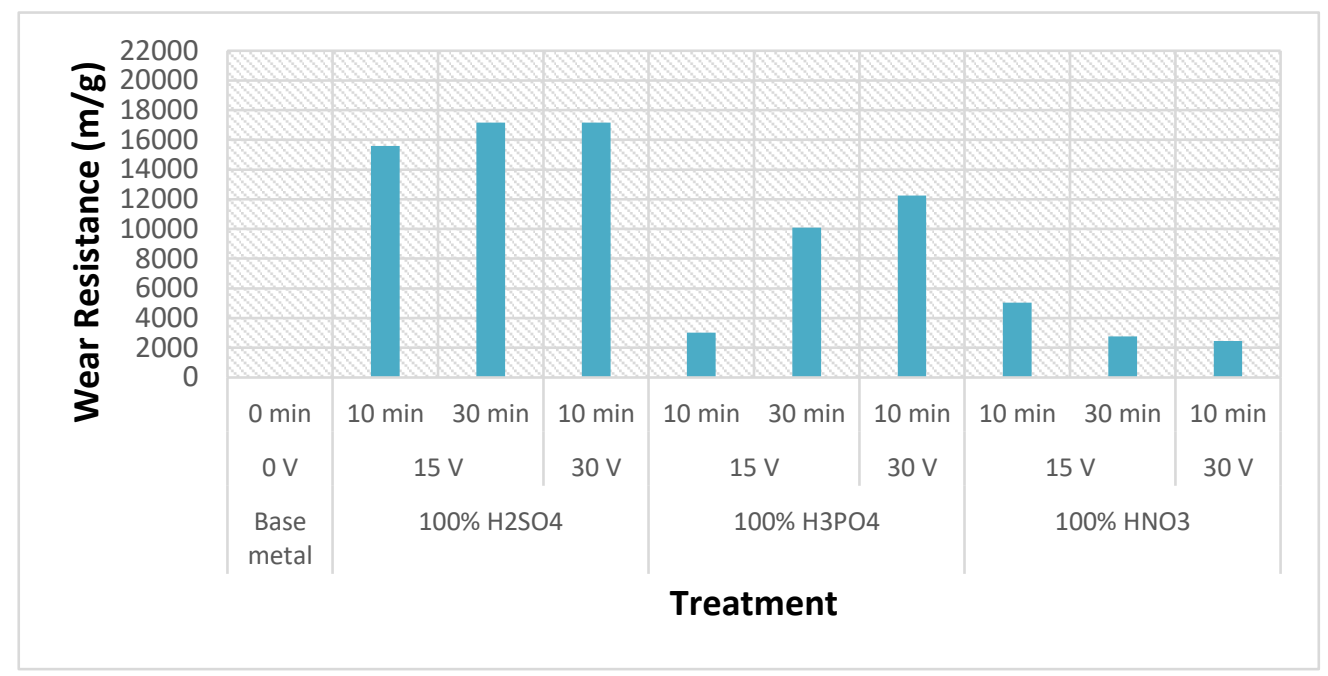

Figure 12. Anodizing wear resistance graph on aluminum 6061

\subsection{Relationship between Coating Thickness and Hardness}



Figure 13. Graph of coating thickness against the surface hardness

The thickness of the oxide coating resulting from the anodizing process has a significant effect on the surface hardness of the specimen. The thicker the resulting coating, the higher 
the hardness rate on the surface. In previous research conducted, it's shown that the increase in the thickness of the anodizing oxide coating is directly proportional to the increase in hardness in aluminum alloys [12]. However, the phenomenon that appears in this study is slightly different, where the thickness of the oxide coating on the surface of aluminum 6061 is the thickest found in specimen number 8, but the highest hardness is found in specimen number 2 . This is presumably because the oxide coating formed on the surface of aluminum 6061 uneven.

\subsection{Relationship between Coating Thickness and Wear Resistance}

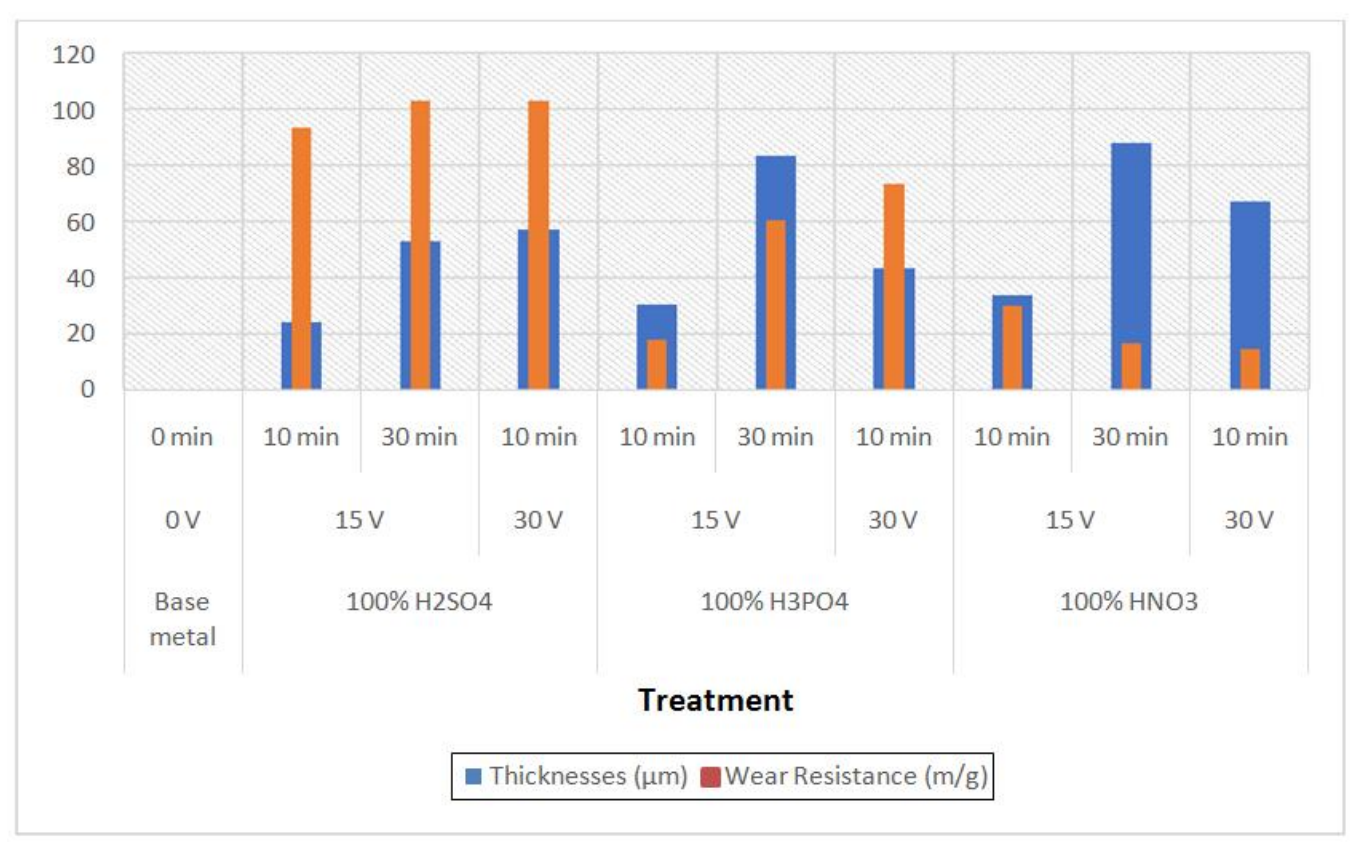

Figure 14. Graph of coating thickness against wear resistance

Figure 14. shows the relationship between the thickness of the oxide coating resulting from the anodizing process and the wear resistance of aluminum 6061. The thicker the oxide coating is produced, the higher the hardness number of aluminum 6061. Thus, the lower the wear rate, this shows the wear resistance of aluminum 6061. the higher it is. The highest wear resistance was achieved by specimens with treatment number 2, but the thickest thickness of the oxide coating was found in specimens with treatment number 8 . This was presumably because the oxide coating formed during the anodizing process was uneven. Previous research stated that the hardness of the material increases with increasing anodizing time, which means that the longer the anodizing time is used, the thicker the oxide coating is. Thus, the thicker the resulting oxide coating will increase the wear resistance of the material [13].

\subsection{Relationship between Surface Hardness and Wear Resistance}

Figure 15. shows that the surface hardness against the wear resistance of aluminum 6061 anodizing results. The highest wear resistance was found in the specimen with the highest hardness number, namely specimen number 2 . The increase in surface hardness was directly related to the increase in wear resistance of the material. Wear resistance is influenced by various aspects, one of which is the voltage on anodizing. Previous research also showed that the higher the voltage used, the higher the wear resistance obtained by the specimen [11]. Thus, the higher the wear resistance of the specimen, the higher the surface hardness obtained. 


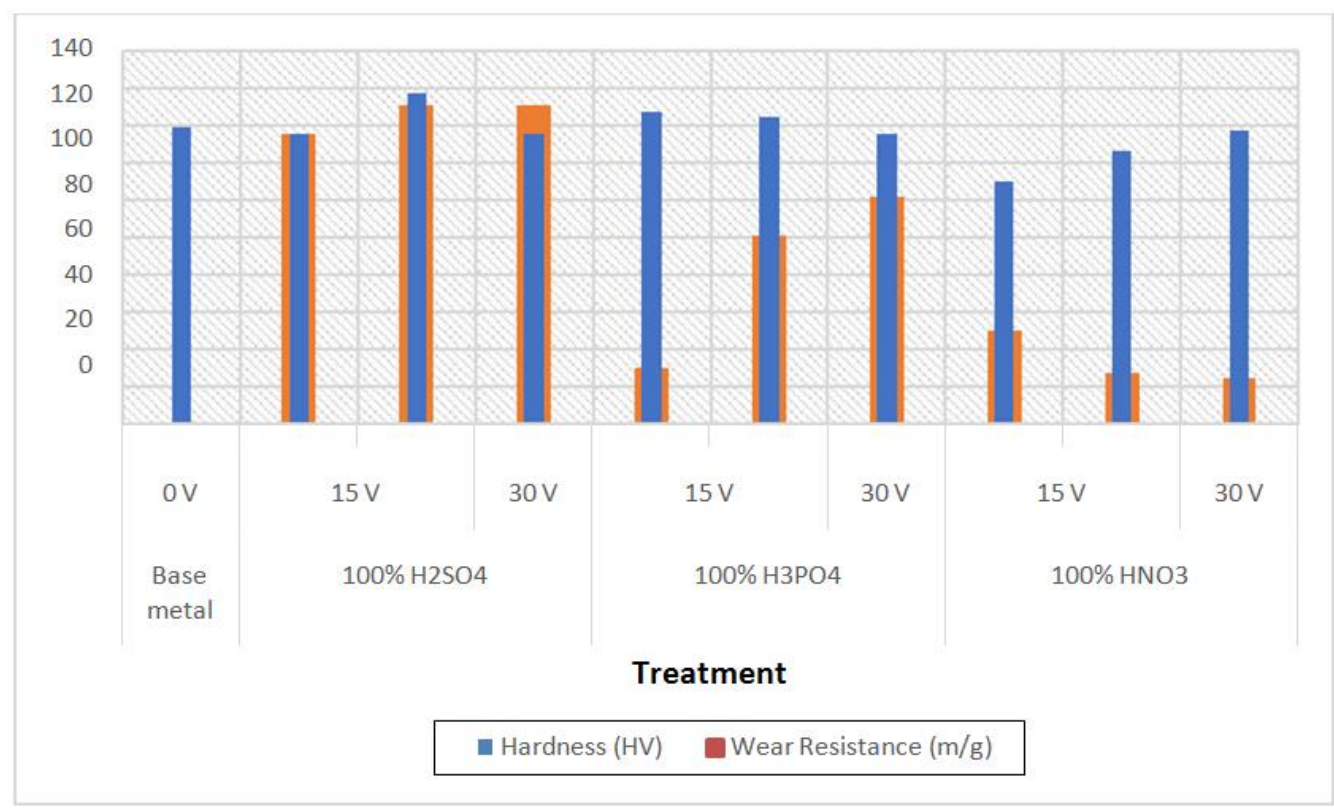

Figure 15. Graph of surface hardness against wear resistance

\section{CONCLUSION}

According to the result and discussion above, thus the following were the conclusions of this study.

1. The highest hardness figure was obtained in the treatment using $100 \% \mathrm{H}_{2} \mathrm{SO}_{4}$ anodizing media, with a voltage of $15 \mathrm{~V}$, which was immersed for 30 minutes. The highest hardness number reaching 106.47 HV was found in specimen number 2, with a coating thickness of $57.025 \mu \mathrm{m}$ and wear resistance of $17153.09 \mathrm{~m} / \mathrm{g}$.

2. The thicker the oxide coating, the higher the surface hardness figure of aluminum 6061 .

3. The higher the hardness number of aluminum 6061, the higher the wear resistance obtained by aluminum 6061 .

4. The increased hardness and wear resistance of 6061 aluminum is significantly affected by voltage and anodizing time.

\section{ACKNOWLEDGEMENTS}

The author would like to thank the Ministry of Research, Technology, and Higher Education of Republic Indonesia for PDUPT Research Grant 2020.

\section{REFERENCES}

[1] DI Tsamroh, P Puspitasari, Andoko, MIN Sasongko, C Yazirin. Comparison Study on Mechanical Properties Single Step and Three Step Artificial Aging on Duralium. AIP Conference Proceedings, 1887(2017)

[2] D.I Tsamroh, Andoko, P. Puspitasari, A.A Permanasari, P.E Setyawan. Optimization of Multistage Artificial Aging Parameters on Al-Cu Alloy Mechanical Properties, Journal of Achievements in Materials and Manufacturing Engineering, 87 (2018)

[3] Agus Suprapto, Pungky Setyawan, Aries Setiawan, Dewi Tsamroh, The Effect of Anodizing Solution Type Against the Coating Thickness and Wear Rateof Aluminum 6061. International Journal of Mechanical Engineering and Technology 10 (12), 2019, pp. 57-64. 
Investigation of Coating Thickness, Hardness and Wear Resistance of Aluminum 6061 by Anodizing Treatment

[4] F. Nugroho, G. Widyatmoko, M. P. B. et.al. Pengaruh Variasi Larutan Elektrolit Terhadap Warna dan Kekerasan Lapisan Hasil Proses Anodizing. Angkasa: Jurnal Ilmiah Bidang Teknologi(2013)

[5] AA Arisudana Wisnu Kusuma Ketut, Wayan Karyasa, and I Nyoman Suardana. Metal Aluminum Anodizing Potential with Different Variations. the e-Journal of Chemistry Visvitalis, Ganesha Education University, 2 (2014),.138-145

[6] Agus Suprapto dan Agus Suyatno (2013), "Pengaruh variasi komposisi degreasing dan waktu anodizing terhadap laju keausan dan ketahanan aus", TRANSMISI, Vol-IX Edisi-1/ Hal. 893902

[7] Ananto, Deriga Dwi. Analisa Pengaruh Bahan dan Waktu Proses Anodizing Terhadap Kekerasan dan Ketebalan Permukaan Aluminium Seri 5052 dengan 6061. (2019), Institut Teknologi Nasional Malang.

[8] Fajar Nugroho. Pengaruh rapat arus dan waktu anodizing terhadap laju keausan permukaan pada Aluminium Paduan AA 2024-T3, Jurnal Foundry, Vol 4, No 1, April 2014, p. 1-8 (2014)

[9] Setiawan, S.W. Pengaruh Variasi Arus Proses Anodizing terhadap ketebalan lapisan Oksida dan Kekerasan Permukaan Aluminium, Yogyakarta, Univ. Sanata Dharma (2018)

[10] Ofoegbu, S.U.; Fernandes, F.A.; Pereira, A.B. The Sealing Step in Aluminum Anodizing: A Focus on Sustainable Strategies for Enhancing Both Energy Efficiency and Corrosion Resistance. Coatings 2020, 10, 226.

[11] Sidharta, Wahyu Bambang. Pengaruh Konsentrasi Elektrolit dan Waktu Anodisasi Terhadap Ketahanan Aus, Kekerasan Serta Ketebalan Lapisan Oksida Paduan Aluminium pada Material Piston. Jurnal teknologi technoscientia, (2014) 7(1): 20-21

[12] L.Zhang, G. Thompson, M. Curioni, et. al. Anodizing of Aluminum in Sulfuric Acid/Boric Acid Mixed Electrolyte, Journal of The Electrochemical Society (2013)

[13] T. Kao, Y. Chang. Influence of Anodization Parameters on The Volume Expansion of Anodic Aluminum Oxide Formed in Mixed Solution of Phosphoric and Oxalic Acids. Applied Surface Science. (2014) 